\title{
Correction: C-X-C motif chemokine ligand 10 produced by mouse Sertoli cells in response to mumps virus infection induces male germ cell apoptosis
}

Qian Jiang ${ }^{1}$, Fei Wang ${ }^{1}$, Lili Shi ${ }^{1}$, Xiang Zhao ${ }^{1}$, Maolei Gong ${ }^{1}$, Weihua Liu ${ }^{1}$, Chengyi Song ${ }^{2}$, Qihan Li ${ }^{3}$, Yongmei Chen ${ }^{1}$, Han $\mathrm{Wu}^{1,2}$ and Daishu Han'

Correction to: Cell Death \& Disease 8, e3146; https:// doi.org/10.1038/cddis.2017.560; published online: 26 Oct 2017.
The PDF and HTML versions of the article have been updated to include the Creative Commons Attribution 4.0 International License information.

Published online: 16 July 2018

Correspondence: Han Wu (yzwuhan@hotmail.com) or

Daishu Han (dshan@ibms.pumc.edu.cn)

${ }^{1}$ Department of Cell Biology, Institute of Basic Medical Sciences, Chinese

Academy of Medical Sciences, School of Basic Medicine, Peking Union Medical College, Beijing, China

${ }^{2}$ Joint International Research Laboratory of Agriculture and Agri-product

Safety, Institute of Epigenetics and Epigenomics, College of Animal Science

and Technology, Yangzhou University, Yangzhou, China

${ }^{3}$ Institute of Medical Biology, Chinese Academy of Medical Sciences, Kunming,

China

(c) The Author(s) 2018

(c) Open Access This article is licensed under a Creative Commons Attribution 4.0 International License, which permits use, sharing, adaptation, distribution and reproduction in any medium or format, as long as you give appropriate credit to the original author(s) and the source, provide a link to the Creative Commons license, and indicate if changes were made. The images or other third party material in this article are included in the article's Creative Commons license, unless indicated otherwise in a credit line to the material. If material is not included in the article's Creative Commons license and your intended use is not permitted by statutory regulation or exceeds the permitted use, you will need to obtain permission directly from the copyright holder. To view a copy of this license, visit http://creativecommons.org/licenses/by/4.0/. 